\title{
MPG wt Allele
}

National Cancer Institute

\section{Source}

National Cancer Institute. MPG wt Allele. NCI Thesaurus. Code C94721.

Human MPG wild-type allele is located in the vicinity of $16 p 13.3$ and is approximately $9 \mathrm{~kb}$ in length. This allele, which encodes DNA-3-methyladenine glycosylase protein, is involved in the regulation of base excision repair of alkylated DNA. 